\title{
Raw milk producers with high levels of hygiene and safety - CORRIGENDUM
}

A. C. Berge and T. Baars

\section{Corrigendum}

Cite this article: Berge AC, Baars T (2020). Raw milk producers with high levels of hygiene and safety - CORRIGENDUM. Epidemiology and Infection 148, e77, 1. https://doi.org/10.1017/ S0950268820000709

doi: https://doi.org/10.1017/S0950268820000060, Published online by Cambridge University Press, 31 January 2020

\section{Original:}

Financial support. This research received no specific grant from any funding agency, commercial or not-for-profit sectors.

Conflict of interest. None. TB is an advisor of the German Vorzugsmilch producers.

\section{Correction:}

Financial support. The authors received no funding for preparation of the manuscript. The authors received funding to cover open access publication fees from the non-profit organization RAWMI.

Conflicts of Interest. ACB and TB both provided unpaid service on the Board of Directors of the non-profit organization RAWMI prior to preparing and submitting this manuscript, and ACB was a founding member of RAWMI. TB recently provided unpaid scientific testimony in legal proceedings, on behalf of raw milk producer applicant, challenging Canada's ban on raw milk. TB is an advisor of the German Vorzugsmilch producers.

\section{Reference}

Berge A and Baars T (2020) Raw milk producers with high levels of hygiene and safety. Epidemiology and Infection, 148, E14. doi:10.1017/S0950268820000060

\section{CAMBRIDGE UNIVERSITY PRESS}

